\title{
The Internationalisation Process of the Smaller Firm: An Examination of the Craft Microenterprise
}

\author{
Ian Fillis
}

Department of Marketing, Faculty of Management, University of Stirling, Stirling, FK9 4LA, UK

\begin{abstract}
This work involves an examination of the internationalisation process of the smaller firm, focusing on the craft enterprise in the United Kingdom and the Republic of Ireland. Craft sector analysis was carried out in order to determine historical precedents as well as to assist in the identification of industry and firm level factors impinging upon domestic and export market behaviour. A range of internationalisation theories are discussed, with the conclusion that the majority of these frameworks fail to readily explain smaller firm exporting behaviour. More recent developments such as the born global firm, the instant international and networking for internationalisation are deemed more appropriate fits for smaller firm internationalisation research. Quantitative results identify the majority of craft firms as microenterprises with almost one half operating as a single person business. Qualitative analysis enabled profiling of craft firm types to be carried out. Four orientations are uncovered: the entrepreneur, the idealist, the lifestyler and the latecomer. A composite framework of the factors uncovered in the analysis is constructed in order to better explain the process of smaller firm internationalisation.
\end{abstract}

Keywords: Internationalisation, smaller firm, exporting, entrepreneurship, craft, creativity.

\section{INTRODUCTION: A REVIEW OF INTERNATION- ALISATION RESEARCH}

Internationalisation has been used to describe the outward movement or increasing involvement in a firm's or larger grouping's international operations [1, 2]. With more and more smaller firms now internationalising, Yakhlef and Maubourguet [3] focus on the reasons for this, such as gaining access to increasing amounts of tangible and intangible resources in order to establish firm-specific global advantages. The stages theory of internationalisation postulates that, in order to develop their international operations, firms use a stepwise approach along an organisational continuum [4]. The Uppsalla School views internationalisation as having four stages [5] while it has also been modelled with five and six $[6,7]$. Although the number of incremental steps may differ, there is general agreement that with each subsequent step comes increasing involvement in international operations [8]. However, due to increasing globalisation, chaotic market conditions and technology effects, it is believed that such stepwise advancement is not generally exhibited in SMEs and that alternative modelling of microenterprise behaviour is needed in order to account for emerging modes of behaviour [9]. Long standing conceptualisations such as transaction cost analysis and the eclectic paradigm [10] fail to satisfactorily explain smaller firm internationalisation behaviour. Recent conceptualisations have, for example, centred on the network approach which more accurately portrays SME behaviour [11-13].

*Address correspondence to this author at the Department of Marketing, Faculty of Management, University of Stirling, Stirling, FK9 4LA, UK; Tel: 01786 467392; Fax: 01786 464745; E-mail: i.r.fillis@stir.ac.uk
Analysis of the literature shows that internationalisation research originally focused on the activities of the multinational enterprise before shifting attention to a certain extent to the behaviour of the small and medium sized enterprise due to its increasing influence on international markets through globalisation and technology effects [14-21]. Research has also shown that there are sectoral differences in internationalisation behaviour [22].

\section{Internationalisation and Firm Size}

One of the key themes in internationalisation research has been the effect of firm size on internationalisation behaviour. Perceptions vary as to what constitutes a small, medium or large firm. The majority of the literature is derived from USA studies where definitions of size differ from the United Kingdom, Europe and elsewhere [23, 24]. The transferability of findings and replicability of studies is therefore difficult to achieve, given these differences. In addition, much of the existing theory today is still dominated by early conceptualisations, with many textbooks continuing to promote the use of these frameworks as an aid to understanding internationalisation of the firm several decades after the initial work was carried out [25, 26], although Hollensen [27] provides a useful comparison of several more contemporary approaches.

In order to move theory forward, both testing of existing conceptualisations and forming of new frameworks based on industry specific studies and emerging behavioural patterns are needed. Much of the theory developed so far has examined industries where firms can progress to carrying out mass production and mass specialisation. An analysis of the craft sector offers the opportunity to examine what happens when the product is produced on a one-off or small batch 
basis and where owner/manager philosophy dominates over many external motivating influences. Most of the frameworks developed so far have tended to focus on the firm passing through a number of stages as it develops from the small domestic based firm to the multinational enterprise. Results will show that for industry sectors dominated by the smaller firm, together with the impact of product and lifestyle issues, this progression is not necessarily observed. Attempts to apply existing theory to such firm behaviour therefore tends to break down. In addition to adaptation of existing internationalisation frameworks, alternative visualisations are needed in order to portray behaviour more accurately.

\section{Internationalisation Theory}

The various theories of internationalisation seek to illustrate the configurations which companies adopt, while also prescribing a normative approach to internationalisation decision making. Tookey [28] and Wind et al. [29] were some of the earliest proponents of the stages approach, while Johanson and Wiedersheim-Paul [5], Johanson and Vahlne [1] and Bilkey and Tesar [6] produced works which still form the basis for much research today. However, there have been various criticisms made regarding the theoretical validity of the concept while empirical evidence from other studies has also tended to contradict these findings [30]. HurmerintaPeltomaki [31] senses that the days of stages theory are numbered and that there is a moving away from its linear time based approach to a more primitive concept of cyclical time with no fixed direction. Bell et al. [32] also review the criticisms of the stages approach while Moen et al. [33] provide a useful critique of the process models of internationalisation in a study of internationalising small computer software firms. Westhead et al. [34] examine the internationalisation strategies of SMEs in rural and urban areas. This has particular relevance to the craft sector discussed later in this paper where many internationalising firms are rurally based.

Difficulties arise when endeavouring to derive a general definition of internationalisation and also when trying to classify the various stages of the process [35]. A number of studies focus on internationalisation through export activity and export orientation and, although they are related, they are not identical. Turnbull's research of British companies show that the internationalisation stage is determined by the operating environment, the industry structure and the marketing strategy of the company. The stages concept should therefore only be used as a classification framework and not as a means of learning how firms internationalise. Bilkey [14] undertook a review of the literature concerning export behaviour of the firm, covering areas such as export initiation, motivations for exporting, firm size effect and export models. He concluded that exporting is a developmental process and that export profiles should be used together with export behaviour models to achieve meaningful results. This procedure is adopted in the investigation of smaller craft firm internationalisation detailed later in this paper.

\section{Exporting as a Path to Internationalisation}

Key research themes relating to the exporting SME include the investigation of the process itself [36,37], market entry and the role of the decision maker [38], SMEs and globalisation [39], exporting stimuli [40], export problems and barriers [41, 42], the link between firm/managerial characteristics and exporting competencies [43] and export stimulation measures [44]. Other issues investigated include comparisons of non-exporters versus exporters [45], networking and the entrepreneurial exporter $[15,46]$, the impact of the internet on SME domestic and export behaviour [47], export market information gathering [48] and the use of creativity to overcome resource constraints [49]. A growing related field is that of international entrepreneurship which acknowledges changing patterns in internationalisation behaviour and connects with born global and instant international phenomena [50].

\section{PROGRESS IN SME INTERNATIONALISATION AND EXPORTING STUDIES}

The smaller international firm can exist in tandem with the larger player through its ability to offer a flexible, customised product and service, enhanced by intuitive networking and other entrepreneurially-based competencies linked to creativity, innovation and relationship building [22, 51-53]. Researchers are now examining the phenomenon of 'instant' or 'born global' internationalising firms in a number of sectors, from hi-tech industries $[32,54,55]$ to the entrepreneurial arts and craft firm. Jolly et al. [56] focus on the ability of entrepreneurially inclined start-up companies to pursue global strategies "by leapfrogging some of the traditional intermediate stages of internationalisation (to become) significant global players...in a relatively short time.' They identify sets of entrepreneurial competencies as drivers of competitive advantage, such as having a global vision, a focused approach to doing business, the ability to recognise technological opportunities and to capitalise on them, facilitated by the insight of the founder of the organisation.

By operating in niche markets and utilising their distinct sets of competencies, the smaller firm can compete with larger organisations, despite resource limitations. Madsen and Servais [57] examine the usefulness of the network approach and evolutionary economics in order to provide an improved explanation of 'born global' behaviour. In addition, they draw on the work of Oviatt and McDougall [58] who identify the International New Venture as an organisation which may initially have one or a few employees (the microenterprise) but has a proactive international strategy from inception of the business [59]. Madsen and Servais also promote the need to understand the background characteristics of the founder of the organisation in shaping internationalisation behaviour. They also call for an integration of the literatures on internationalisation and entrepreneurship in order to improve understanding of the 'born global' firm while also understanding the particular behaviour of firms by size.

There is a growing interest in smaller internationalising entrepreneurial firms $[60,61]$. Defining international entrepreneurship is still in a state of evolution. McDougall [62] saw it as focusing on the international activities of new ventures, rather than including already established firms but then this has largely been the case in entrepreneurial research generally. Wright and Ricks [63] viewed international entrepreneurship as a firm-level business activity which crossed national borders and which involved inter-relationships between the business and the international environment. 
McDougall and Oviatt [60] define the concept as a combination of innovative, proactive, and risk-seeking behaviour that crosses national borders and is intended to create value in organisations The field of international entrepreneurship is growing markedly and this has been recognised by the launch of the Journal of International Entrepreneurship in 2003. Recent issues have covered topics such as international entrepreneurship and the internet [60, 64], branding strategies of born globals [65] and micro multinationals [66].

Summarising the key influencing factors on smaller firm internationalisation, it can be seen that exporting issues dominate such behaviour. The literature concentrates on issues such as firm size effect on internationalisation, motivation for exporting, export barriers and characteristics of the export decision maker and the decision to export. Further contributing factors which also impinge upon the process to varying degrees include the behaviour of the entrepreneurial firm in comparison with other firm types, the effect of culture on the internationalisation process, the use of export marketing research and the impact of export marketing assistance programmes. These factors are found to subsequently impact upon exporting strategy and performance and on owner/manager evaluation of export profitability and success. Fig. (1) indicates how these factors interact in forming smaller firm exporting behaviour:

\section{THE INTERNATIONALISATION PROCESS OF THE SMALLER CRAFT FIRM}

Previous theories of internationalisation have failed to provide a reasonable explanation for the behaviour of the smaller exporting craft firm. Given that the craft sector has particular peculiarities in that the majority of craft firms appear not to follow a pattern of growth as described in much existing internationalisation theory, there are merits for the application of other paradigms of understanding linked to entrepreneurship and creativity. By examining the historical development of the craft firm, evidence of creative entrepreneurial practice can be found spanning several centuries. This should also prove valuable to the owner/manager of any smaller firm involved in domestic and international markets.

Historically, the craft firm can be traced at least to the Medieval period [67], through to the Italian Renaissance [68] and the Arts and Crafts period of the late nineteenth and early twentieth centuries [69]. The nature and meaning of craft has altered during these times, from the early vernacular status to the more recent aesthetic appreciation of the craft product [70]. A major problem related to tracing the development of the crafts as a recognised industry is that when examining historical documents there does not appear to be a consensus of opinion regarding its definition [71]. Its present connotation encapsulates a number of ideas drawn from philosophy, aesthetics and technology [72]. Metcalf [73] makes the distinction between craft as skilful labour and craft as a class of objects. Concentrating on the latter category, he sees this as embracing the idea that the object must have a high degree of hand-made input, either by using the hand itself, handtools and even hand-held power tools. Further more, the craft object does not necessarily have to be produced using traditional materials, only that traditional/conventional methods should have been used as part of the production process.

Now, in the post industrialisation era, the craftsperson has to compete with both domestic and foreign competition where many products appear hand-crafted even though they are mass produced via advanced technological processes. The crafts sector is now viewed as part of the greater cultural and creative industries $[74,75]$. The craft product itself must exhibit aesthetic appeal, be of individual design and contain a large degree of manual skill in its production. In surveying craft firms in the United Kingdom and the Republic of Ireland, the author has attempted to identify those crafts which involve a high degree of manual input, either manufactured

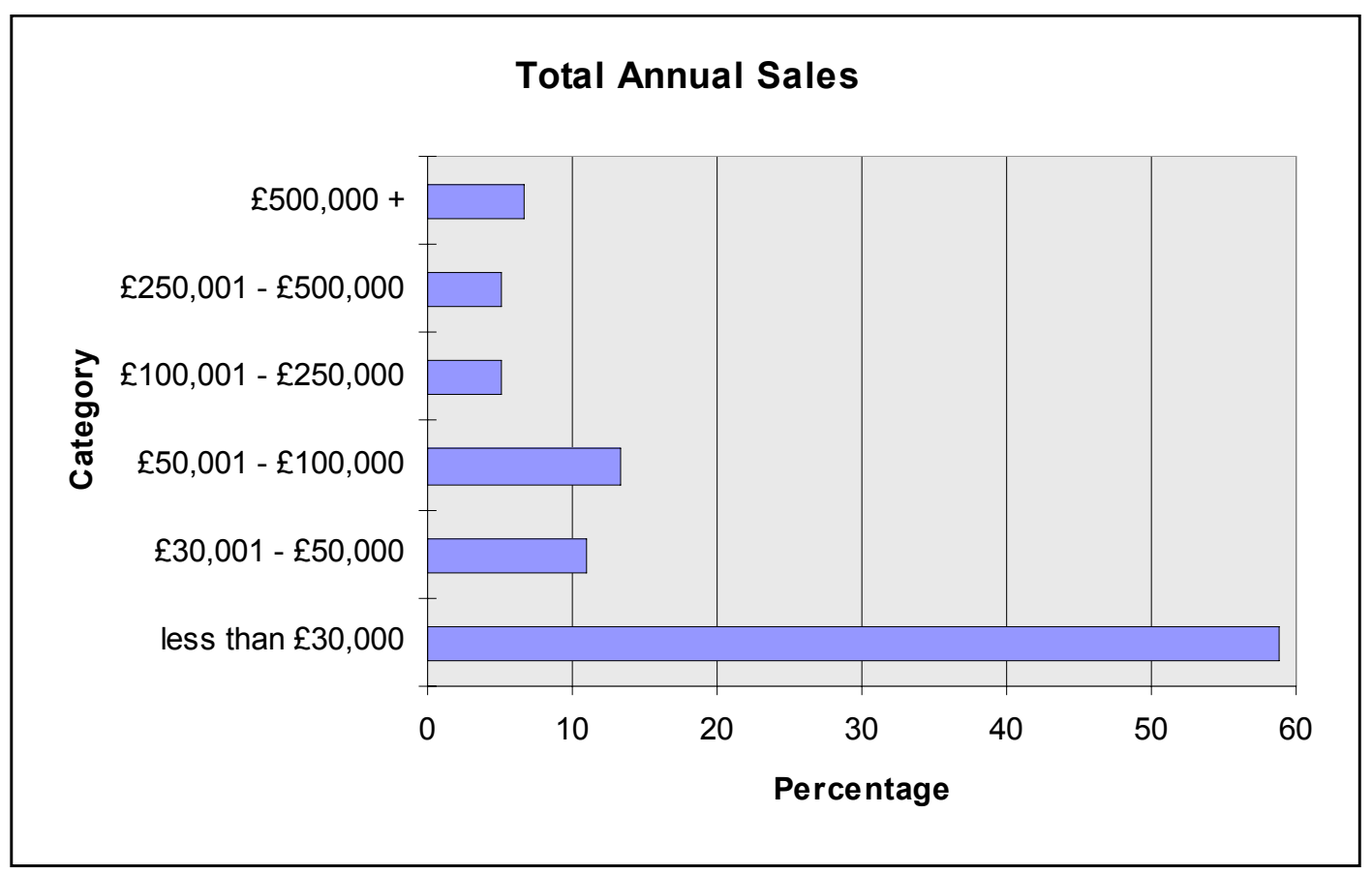

Fig. (1). Total sales generated. 
as one-off items, or in small batches. As such, this will then have implications for issues such as the time available for export decision making and acquiring entrepreneurial and marketing skills.

\section{RESEARCH PROPOSITIONS}

Several propositions contributing to smaller firm internationalisation can be derived from this literature review. The propositions centre around the notion that despite sometimes severe resource constraints, microenterprises can and do internationalise but their behaviour and progression is sometimes at odds with existing frameworks of internationalisation.

Proposition 1: The majority of existing internationalisation frameworks fail to explain contemporary smaller firm internationalisation behaviour.

Proposition 2: Alternative conceptualisations focusing on entrepreneurial thinking and creativity are needed in order to secure a better fit.

Proposition 3: Analysis of craft firm internationalisation will provide a range of contrasting findings compared to previous internationalisation studies.

Proposition 4: Given the dominance of the microenterprise in the craft sector, owner/manager influences will dominate internationalisation behaviour of such firms.

Proposition 5: Competencies such as creativity, opportunity recognition and networking ability will result in competitive advantage for the internationalising microenterprise.

\section{METHODOLOGY}

The methodology adopted was pluralistic in nature, incorporating both qualitative and quantitative approaches. Due to the specific problems of defining the craft industry and the difficulties in sampling from a single recognised source, the decision was made to carry out a quantitative survey of 500 craft business in England, Scotland, Wales, Northern Ireland and the Republic of Ireland in order to firstly identify exporting and non-exporting craft firms. The number of usable responses was $25 \%$, comparing favourably to similar exporting behaviour studies [48]. The second stage involved follow up interviews with thirty exporting and nonexporting craft business owner/managers in order to test the initial findings and also to explore additional themes such as the choice of export market of the Celtic craft firm, and to facilitate the building of craft firm typologies. Statistical analysis was carried out on the questionnaire data [76]. This was then followed by qualitative analysis and interpretation of the in-depth interviews [77] where recurring themes were identified and the findings were compared and contrasted with the initial quantitative study in order to enhance understanding.

\section{QUANTITATIVE RESULTS}

Approaching one half of all respondents (47.5\%) operate on an individual basis (Table 1). Over one third of craft business owner/managers employ between two and five people. The remaining $15 \%$ are dispersed over several other categories. However, no craft business in the survey was identified as employing between 50 and 99, and more than 200 people. Well over half of respondents $(58.8 \%)$ recorded total annual sales of less than $£ 30,000$. More than $10 \%$ experience sales of between $£ 30,001$ and $£ 50,000$, while over $13 \%$ have sales of between $£ 50,001$ and $£ 100,000$. At the other end of the scale, $6.7 \%$ of respondents have experienced sales of over $£ 500,000$. Respondents were asked to indicate the level of annual sales generated through exporting. Well over half of exporters achieved export sales of less than $£ 10,000$, with over one fifth achieving sales of between $£ 10,001$ and $£ 25,000$. However, at the other end of the range, five exporters achieved sales of over $£ 100,001$, with three reaching in excess of $£ 250,000$. Exports, on average, accounted for just over $38 \%$ of total sales.

Table 1. Craft Firm Employment Levels

\begin{tabular}{|c|c|c|}
\hline Category & Frequency & Percentage \\
\hline \hline single person & 58 & 47.5 \\
\hline $2-5$ & 46 & 37.7 \\
\hline $6-10$ & 7 & 5.7 \\
\hline $11-25$ & 7 & 5.7 \\
\hline $26-49$ & 2 & 1.6 \\
\hline $50-99$ & 0 & 0 \\
\hline $100-199$ & 2 & 1.6 \\
\hline $200+$ & 0 & 0 \\
\hline Total & 122 & 100 \\
\hline
\end{tabular}

\section{Motivation for Exporting}

Respondents were asked to indicate on a 5-point Likert scale, with 5 being very important to 1 being not at all important, the main positive and negative influences on the decision to export (Table 2) The most important factors inhibiting export activity were that the owner/managers did not believe they had enough production capacity $($ mean $=3.67)$; the business was too small in general (mean = 3.54); the owner/manager did not have enough time to research new markets (3.16) and that they lacked sufficient marketing knowledge $($ mean $=3.05)$. The least influential factor related to the owner/manager not having travelled overseas before. Having sufficient business in the domestic market is a major factor in the decision not to export. Other reasons of above average importance are lack of export inquiries, relating to the reactive approach to business; complicated exporting procedures; poor levels of exporting assistance and limited government incentives. Issues which caused least difficulty related to lack of appropriate marketing information and distribution channel structure. The small size of the craft firm in the survey reflects the findings of previous work in the sector. It also relates to the observations by Storey (1994) with respect to the dominance of the microenterprise in Europe.

\section{Export Markets and Exporting Success}

The main export markets were European Union countries $(35.7 \%)$, followed by North America $(30.2 \%)$. There were differences in export market choice by firms from Northern Ireland, the Republic of Ireland, England, Scotland and Wales, although the only statistical significant destination was the Far East $(\mathrm{phi}=0.440$; sig. $=.029)$. Differences were 
found in owner/manager perception of the role of geographical distance upon the choice of export market $(\mathrm{p}=.013)$. Attitudinal differences were found among exporter groups in terms of the influencing effect of unsolicited orders and the wish to rely less on domestic market sales $(p=.039)$. There appears to be a relationship between previous exporting activity by those no longer exporting, total annual sales achieved and the age of the owner/manager $(\mathrm{p}=.027 ; \mathrm{p}=$ $.017)$. This suggests that, despite gaining exporting experience, a number of firms have reverted to domestic-based activities, reflecting the impact of factors such as lifestyle and motivation on craft firm internationalisation behaviour which are detailed in the qualitative results. One-way analysis of variance tests were also carried out on exporter and non-exporter groups, and support the findings of the chisquare tests.

Table 2. Firm and Managerial Factors Impinging Upon the Decision Not to Export

\begin{tabular}{|l|c|c|}
\hline \multicolumn{1}{|c|}{ Reasons } & Mean Score & Rank \\
\hline \hline not enough production capacity & 3.67 & 1 \\
\hline business too small to handle exporting & 3.54 & 2 \\
\hline no time to research new markets & 3.16 & 3 \\
\hline lack of marketing knowledge & 3.05 & 4 \\
\hline lack of financial resources & 3.02 & 5 \\
\hline no motivation to export & 2.95 & 6 \\
\hline lack of personnel & 2.65 & 7 \\
\hline lack of business experience & 2.59 & 8 \\
\hline exporting is too risky & 2.58 & 9 \\
\hline no time to research cultural differences & 2.46 & $10=$ \\
\hline no time to research language differences & 2.46 & $10=$ \\
\hline unwilling to investigate new markets & 2.19 & 12 \\
\hline have not travelled abroad & 1.59 & 13 \\
\hline
\end{tabular}

Export market access was obtained primarily through international trade shows and exhibitions (32.5\%), direct sales $(15.4 \%)$ and the use of networking and personal contacts (11.4\% of exporters). However, when questioned specifically about the use of networks, over one quarter of respondents confirmed that they utilised networks in order to achieve exports. The most important relationships for exporting success were shown to be with customers $($ mean $=4.87)$, retailers $($ mean $=4.54)$, suppliers $($ mean $=4.07)$, other business contacts $($ mean $=3.87)$ and distributors $($ mean $=3.16)$. Only $7.3 \%$ of current exporters believed that exporting had not resulted in increased business for the firm. The quantitative results demonstrate that the typical exporting smaller craft firm tends to develop low cost internationalisation methods centred around exploitation of personal and business networks, while utilising the company/customer relationship in order to secure business at trade fairs and exhibitions.

\section{Problems Experienced by Exporters}

Over one third of exporting craft firms (36.4\%) indicated that they encountered problems once they entered export markets. The most common problem encountered was with the choice of a reliable distributor, followed by difficulties in promoting the product and matching competitors' prices. The least problematic areas were in identifying and choosing distribution channels for the products and the lack of marketing information. There appears to be a certain degree of conflict between the choice of actual distributor and in how the owner/manager understands the operating mechanism of the distribution channel. Exporting status (whether or not the firm is currently exporting) was found to vary, depending on employment and sales levels $(p=.000 ; p=.002)$. The length of time spent operating in international markets appears to affect the degree of usage of overseas contacts and professional institutions as export information sources $(p=.019 ; p$ $=.042$ ). Results also indicated that the degree of use of contacts in the domestic market to assist international activities varied with exporting experience $(\mathrm{p}=.023)$.

\section{QUALITATIVE RESULTS}

Qualitative analysis has enabled the generation of a profile of craft business owner/managers. There are those who have chosen to work in the industry because of the type of lifestyle involved and are unwilling to sacrifice this in order to expand the business (the lifestyler). Another type of craft owner/manager is the business-oriented entrepreneur who is willing to take risks and recognises the importance of developing a customer base (the entrepreneur). Networking and relationship building are deemed very important for business success. The third type can be described as an artist/designer who is unwilling to view the craft as a product but as a creative entity (the idealist). Their stance is uncompromising when producing the work; they do not tend to take note of customer demand but instead make art/craft which they feel has artistic integrity. In other words, they embrace an 'Art for Art's sake', rather than 'Art for Business sake' philosophy. There is a fourth type who may enter the industry much later than the other groups; they tend to have gained previous work experience in unrelated areas and have decided to make a career change (the late developer). Depending on their background, a number of key skills can be brought into the new venture but the importance of lifestyle quality appears to be significant here too. Table $\mathbf{3}$ summarises the key characteristics found in the four craft business types:

Although qualitative analysis has identified these groups of owner/manager characteristics it should be noted that they are not always mutually exclusive. Several characteristics can be found in more than one group: for instance, both the entrepreneur and the idealist are prepared to take risks. However, it is the nature of the risk that is inherently different. The former is prepared to indulge in risk taking at the business and product level, while the latter is really only concerned with artistic risk. These factors must then be taken into account when considering the internationalisation behaviour of the craft firm and are presented as reasons as to 
Table 3. Craft Business Owner/Manager Characteristics

\begin{tabular}{|c|c|}
\hline $\begin{array}{l}\text { THE LIFESTYLER } \\
\text { - expansion of business not important } \\
\text { - unwilling to take many risks } \\
\text { - importance of quality of life } \\
\text { - may or may not export; generally reactive } \\
\text { - unwilling to follow business and marketing philosophy/skills }\end{array}$ & $\begin{array}{l}\text { THE ENTREPRENEUR } \\
\text { - risk taker (in terms of carrying out business and with the craft product } \\
\text { itself) } \\
\text { - may or may not export - proactive } \\
\text { - willing to accept business and marketing philosophy (to varying degrees) } \\
\text { - realisation of importance of customer relationships/networking }\end{array}$ \\
\hline $\begin{array}{l}\text { THE IDEALIST } \\
\text { - risk taker (with the craft product) } \\
\text { - unwilling to accept business and marketing philosophy } \\
\text { - dominance of 'Art for Art's sake' beliefs } \\
\text { - may or may not export } \\
\text { - realisation of importance of establishing and building relationships and } \\
\text { generating reputation } \\
\text { - views self as artist rather than craftsperson }\end{array}$ & $\begin{array}{l}\text { THE LATE DEVELOPER } \\
\text { - tends to come from non-creative background } \\
\text { - less motivated to expand business; less likely to export } \\
\text { - unlikely to accept 'new' ideas; believe in valuing own experience of busi- } \\
\text { ness and life } \\
\text { - able to bring 'outside skills' to the business } \\
\text { - lifestyle also important }\end{array}$ \\
\hline
\end{tabular}

why such firms appear not to conform to the various stages of export progression identified in studies from other industry sectors.

\section{CONCEPTUALISATION OF CRAFT FIRM IN- TERNATIONALISATION}

Survey results have revealed that the typical craft practitioner follows manual methods of production, either works alone or employs only very small numbers of personnel and experiences limited total annual sales and export sales. This then means that testing of existing theories of internationalisation and export stage development based on the 'traditional firm' is inherently problematic. Other crucial factors have been identified from profiling of both exporting and nonexporting craft enterprises. The particular philosophy followed by the key decision maker affects future business growth. There appears to be a problematic dichotomy of 'art for art's sake' versus 'art for business sake' beliefs. Those following the former approach have no particular wish to embrace marketing in case their artistic standpoint is compromised. Conversely, a number of entrepreneurial marketers have been identified where they have used their creative strength to achieve both domestic and export market sales. Creative use of cultural background has resulted in the production and marketing of culture-related products, as well as in the identification and development of culture-related export markets such as North America. It should also be noted that a number of owner/managers have refused to exploit their cultural background as an aid to business growth but have instead focused on their individual creative design strengths in order to achieve sales. Examination of the craft industry has shown that creative use of limited resources can break down barriers to growth. It should also be noted that creativity can also be a limiting factor in that those owner/managers refusing to embrace business and marketing philosophy will not always be successful; not every producer can rely on reputation as an aid to sales.

Investigation of the smaller craft firm has shown that companies employing less than ten personnel (the microenterprise) can have meaningful international impact. This research has demonstrated that internationalisation of the microenterprise involves a range of factors relating to resource limitation and owner/manager orientation not generally in- corporated in studies of larger sized firms. Internationalisation has previously been described as the process of increasing involvement in international operations [2], or involving the scaling of a strategy-ladder [78]. Examination of smaller craft firm behaviour has shown that many existing methods such as the stages approach and the eclectic paradigm offer limited scope for visualising the internationalisation behaviour of the microenterprise. Conceptualisations such as the born global and instant international are now offered as contemporary evaluations of entrepreneurial smaller internationalising firms. As can be seen from the profiling of the craft firm, increasing involvement of the microenterprise will depend on owner/manager orientation. Investigation of craft firm behaviour has shown that a large proportion of these smaller firms will always remain small, due to the wishes of the owner/manager who drives the firm. Therefore, international progression will only reach a certain point beyond which only those firms with creative and entrepreneurial orientation will tend to pass.

Investigation of smaller craft firm exporting behaviour has reinforced the usefulness of the network paradigm [11, 79] as an aid to understanding smaller firm internationalisation. Due to limitation of resources, the microenterprise must seek low cost methods such as networking and word of mouth communication to facilitate growth. In many cases, export market entry can be gained much more quickly using these approaches than through the adoption of other methods. A range of exporting barriers can be bypassed as the microenterprise forms and exploits links with network members in domestic and overseas markets. Interpretation of exporting success varies, depending on the particular orientation of the owner/manager of the craft enterprise. Although exporting acts as a business expansion factor, results indicate that this rate decreases as the value of export sales increases. This supports the belief that many owner/managers of smaller craft firms are motivated to expand only to a certain point beyond which the increased effort is not deemed to be worthwhile. The dominance of the lifestyle factor exhibited by many owner/managers explains this lack of progression. A fuller comprehension of the internationalisation process of the smaller craft firm can be obtained by combining the various factors influencing exporting behaviour, owner/manager characteristics and smaller craft firm exporting performance and success issues (Fig. 2). 


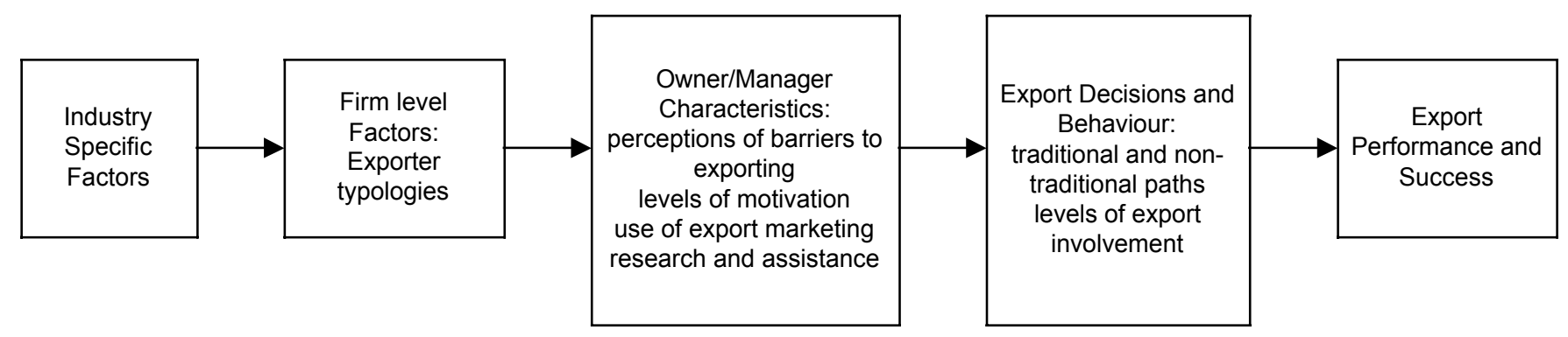

Fig. (2). Interaction of contributing factors in smaller firm exporting behaviour. (Source: The Author).

\section{CONCLUSIONS}

Analysis of the results has shown that owner/manager perception of terminologies such as exporting strategy, business and products vary due to the particular philosophical stance held. Instead of incorporating the exporting strategy dimension into the model following an evaluation of the impact of various internal and external factors on internationalisation, it is perhaps more valuable to include both strategic and cultural dimensions as part of initial owner/manager orientation. Export marketing research attitudes and usage will vary depending on this orientation, but will also be affected by a range of craft sector specific and general smaller firm factors such as predisposition by local support agencies towards providing appropriate exporting assistance geared towards the smaller craft firm. Owner/manager orientation impacts directly upon craft product issues; for example, the idealist will not adapt the product to suit market demand, while many entrepreneurial exporters will tend to exploit the Celtic connection regardless of whether or not they themselves are Celtic in origin. These preceding factors then impact upon export decision making, with a variety of possible outcomes.

Instead of the commonly modelled dichotomous behaviour of export decision making such as the reactive/proactive, aggressive/passive approaches, this research has identified four possible orientations with varying attitudes towards exporting. The idealist and the entrepreneur have the best possibility of developing exports, although different motivational reasons are found in each firm type. Reputation acts to drive the idealist producer through international markets while increasing profits serve to motivate the entrepreneurial craft firm. The latecomer and the lifestyler are the least likely to engage in exporting activity, with both types tending to be more risk averse than the other firm types. Finally, evaluation of exporting performance and success will vary, due to differences in owner/manager philosophy and the outcomes generated over time. The lifestyler and latecomer may be satisfied with a continuing small level of craft exports, as long as they experience no additional stress and inconvenience. However, the idealist and entrepreneur appear strongly motivated to continue exporting, although their individual reasons for doing so will vary.

In conclusion, this research has examined a sector of industry which has not been previously rigorously investigated from entrepreneurship, marketing and international business perspectives. The smaller craft firm shares many common characteristics with other microenterprises and, therefore, these factors should be addressed in future studies of smaller firm internationalisation in other sectors as well as in the wider creative and cultural industries. In addition, this work has also uncovered a range of situation specific issues found to occur within the craft sector. Future internationalisation research on the smaller firm should attempt to incorporate a pluralistic approach based on marketing and entrepreneurship issues, in order to identify a range of shared and situation specific factors which can then be incorporated in the construction of improved theory generation, as well as in advice for industry practitioners.

\section{BIOGRAPHY}

Dr. Ian Fillis is Senior Lecturer in Marketing in the Department of Marketing, Faculty of Management at the University of Stirling, Scotland. He holds a BSc in Civil Engineering from the University of Glasgow, an MA in Marketing from the University of Ulster and a Ph.D. on the internationalisation process of the smaller firm from the University of Stirling. His main research interests focus on issues at the marketing and entrepreneurship interface such as creativity and innovation, in addition to exploring international marketing and export related phenomena.

\section{REFERENCES}

[1] Johanson J, Vahlne J-E. The internationalization process of a firm: a model of knowledge development and increasing foreign market commitments. J Int Bus Studies 1977; 8: 23-32.

[2] Welch LS, Luostarinen R. Internationalization: evolution of a concept. J Gen Man 1988; 14(2): 34-55.

[3] Yakhlef A, Maubourguet F. The lexus and the olive tree: a rising mode of internationalisation. Int J Ent Behav Res 2004; 10(3): 192205.

[4] Lloyd-Reason L, Mughan T. Strategies for internationalisation within SMEs: the key role of the owner-manager. J Small Bus Ent Dev 2002; 9(2): 120-9.

[5] Johanson J, Wiedersheim-Paul F. The internationalisation of the firm-four Swedish cases. J Man Studies 1975; October: 305-22.

[6] Bilkey WJ, Tesar G. The export behaviour of smaller Wisconsin manufacturing firms. J Int Bus Studies 1977; 8: 93-8.

[7] Reid SD. The decision maker and export entry and expansion. J Int Bus Studies 1981; Fall: 101-12.

[8] Yip GS, Biscarri JG, Monti JA. The role of the internationalization process in the performance of newly internationalizing firms. J Int Mark 2000; 8(3): 10-35.

[9] Fillis I. The internationalisation process of the craft firm microenterprise. J Dev Ent 2002; 7(1): 25-43.

[10] Dunning JH. The eclectic paradigm as an envelope for economic and business theories of MNE activity. Int Bus Rev 2000; 9(2): $163-90$.

[11] Johanson J, Mattsson L-G. Internationalisation in Industrial Systems-A Network Approach. In: Hood N, Vahlne J-E, Eds. Strategies in global competition, Croom Helm, The Stockholm School of Economics 1988; pp.198-211.

[12] Ghauri P, Lutz C, Tesfom G. Using networks to solve export marketing problems of small and medium sized firms from developing countries. Eur J Mark 2003; 37(5/6): 728-52. 
[13] Keeble D, Lawson C, Smith HL, Moore B, Wilkinson F. Internationalisation processes, networking and local embeddedness in technology-intensive small firms. Small Bus Econ 2004; 11(4): 327-42.

[14] Bilkey WJ. An attempted integration of the literature on export behaviour. J Int Bus Studies 1978; 9(1): 33-45.

[15] Coviello NE, Munro HJ. Growing the entrepreneurial firmnetworking international market development. Eur J Mark 1995; 29(7): 49-61.

[16] Stray S, Bridgewater S, Murray G. The internationalisation process of small technology-based firms: market selection, mode of choice and degree of internationalisation. J Glob Mark 2001; 15(1): 7-27.

[17] Brush C, Edelman L, Manalova T. "The impact of resources on small firm internationalization. J Small Bus Strategy 2002; 13(1): $1-17$.

[18] Chetty S, Campbell-Hunt C. Paths to internationalisation among small to medium sized firms. A global versus regional approach. Eur J Mark 2003; 37(5/6): 796-820.

[19] Fletcher D. International entrepreneurship and the small business. Ent Reg Dev 2004; 16: 289-305.

[20] Nummela N, Loane S, Bell J. Change in SME internationalisation: an Irish perspective. J Small Bus Ent Dev 2006; 13(4): 562-83.

[21] Ruzzier M, Hisrich RD, Antoncic B. SME internationalisation research: past, present and future. J Small Bus Ent Dev 2006; 13(4): 476-97.

[22] Agndal H, Axelsson B. Internationalisation of the Firm-the Influence of Relationship Sediments. In: Havila V, Forsgren M, Hakansson H, Eds. Critical perspectives on internationalisation Pergamon: New York 2002.

[23] Javalgi RG, Griffith DA, White DS. An empirical examination of factors influencing the internationalization of service firms. J Serv Mark 2003; 17(2): 185-201.

[24] Kalafsky RV. Export activity and firm size: an examination of the machine tool sector. J Small Bus Ent Dev 2004; 11(2): 159-65.

[25] Backhaus K, Buschken J, Voeth M. International Marketing. Basingstoke, England. Palgrave 2005.

[26] Dick H, Merrett D. The Internationalisation Strategies of SmallCountry Firms: the Australian Experience of Globalisation. Cheltenham. Edward Elgar 2007.

[27] Hollensen S. Global Marketing: a Decision-Oriented Approach. London. Prentice Hall 2007.

[28] Tookey D. International business and political geography. Br J Mark 1969; 3(3): 18-29.

[29] Wind Y, Douglas SP, Perlmutter HV. Guidelines for developing international marketing strategies. J Mark 1973; 37: 14-23.

[30] Turnbull PW. A challenge to the stages theory of the internationalization process. In Rosson PJ, Reid SD, Eds. Managing Export Entry and Expansion 1987; 21-40.

[31] Hurmerinta-PeltomÄki L. Time and internationalisation theoretical challenges set by rapid internationalisation. J Int Ent 2004; 1(2): 217-36.

[32] Bell J, Crick D, Young S. Small firm internationalization and business strategy: an exploratory study of 'knowledge intensive' and 'traditional' manufacturing firms in the UK. Int Small Bus J 2004; 22(1): 23-56.

[33] Moen O, Gavlen M, Endresen I. Internationalization of small computer software firms. Eur J Mark 2004; 38(9/10): 1236-51.

[34] Westhead P, Ucbasaran D, Binks M. Internationalization strategies selected by established rural and urban SMEs. J Small Bus Enterprise Dev 2004; 11(1): 8-22.

[35] Axinn CN, Matthyssens P. Limitations of internationalization theories in an unlimited world. Int Mark Rev 2002; 19(5): 436-49.

[36] Fillis I. Small firm internationalisation: an investigative survey and future research directions. Man Decis 2001; 39(9): 767-83.

[37] Cadogan J, Diamantopoulos A, Siguaw JA. Export market-oriented activities: their antecedents and performance consequences. J Int Bus Studies 2002; 33(3): 615-26.

[38] Ojala A, Tyrvainen P. Market entry decisions of US small and medium-sized software firms. Man Decis 2008; 46(2): 187-200.

[39] Winch GW, Bianchi C. Drivers and dynamic processes for SMEs going global. J Small Bus Ent Dev 2006; 13(1): 73-88.

[40] Rundh B. International marketing behaviour among exporting firms. Eur J Mark 2007; 41(1-2): 181-98.

[41] Fillis I. Barriers to internationalisation: an investigation of the craft microenterprise. Eur J Mark 2002; 36(7/8): 912-27.
[42] Leonidou LC. An analysis of the barriers hindering small business export development. J Small Bus Man 2004; 42(3): 279-302.

[43] Grimes A, Doole I, Kitchen PJ. Profiling the capabilities of SMEs to compete internationally. J Small Bus Enterprise Dev 2007; 14(1): 64-80.

[44] Leonidou LC, Katsikeas CS, Palihawadana H, Spyropoulou S. An analytical review of the factors stimulating smaller firms to export: implications for policy makers. Int Mark Rev 2007; 24(6): 735-70.

[45] Requena-Silvente $F$. The decision to enter and exit foreign markets: evidence from UK SMEs, Small Bus Econ 2005; 25(3): 237-53.

[46] Babakus E, Yavas U, Haahti A. Perceived uncertainty, networking and export performance. a study of Nordic SMEs. Eur Bus Rev 2006; 18(1): 4-13.

[47] Gilmore A, Gallagher D, Henry S. E-marketing and SMEs: operational lessons for the future. Eur Bus Rev 2007; 19(3): 234-47.

[48] Williams JEM. Export marketing information gathering and processing in small and medium-sized enterprises. Mark Int Plan 2006; 24(5): 477-92.

[49] Fillis I. Celtic craft and the creative consciousness as contributions to marketing creativity. J Strategic Mark 2007; 15(1): 7-16.

[50] Fillis I. A methodology for researching international entrepreneurship in SMEs: a challenge to the status quo. J Small Bus Ent Dev 2007; 14(1): 118-35

[51] Fillis I. An examination of the internationalisation process of the smaller craft firm in the United Kingdom and the Republic of Ireland. PhD [thesis] Stirling: University of Stirling 2000.

[52] Fillis I. Being creative at the marketing/entrepreneurship interface: Lessons from the art industry. J Res Mark Ent 2000; 2(2): 125-37.

[53] Fillis I, McAuley A. Modelling and measuring creativity at the interface. J Mark Theory Pract 2000; 8(2): 8-17.

[54] Knight G, Cavusgil ST. Innovation, organizational capabilities and the born global firm. J Int Bus Studies 2004; 35(2): 124-41.

[55] Rialp A, Rialp J, Knight GA. The phenomenon of early internationalizing firms: what do we know after a decade (1993-2003) of scientific enquiry? Int Bus Rev 2005; 14(2): 147-66.

[56] Jolly VK, Alahuhta M, Jeannet J-P. Challenging the incumbents: how high technology start-ups compete globally. J Strategic Change 1992; 1: 71-82.

[57] Madsen TK, Servais P. The internationalisation of born globals: an evolutionary process? Int Bus Rev 1997; 6(6): 561-83.

[58] Oviatt BM, McDougall PP. Toward a theory of international new ventures. J Int Bus Studies 1993; 24: 45-64.

[59] Zahra SA. A theory of international new ventures: a decade of research. J Int Bus Studies 2005; 36(1): 20-8.

[60] McDougall PP, Oviatt BM. International entrepreneurship: the intersection of two research paths. Acad Man J 2000; 43(5): 902-6.

[61] Cubillo JM, Cerviño J. International entrepreneurship in local SME supplier networks. Int J Ent Innovation 2004; 5(4): 231-9.

[62] McDougall PP. International versus domestic entrepreneurship: a comparison of new venture behaviour and industry structure in the computer and communications industries. J Bus Venturing 1989; 4: 387-400.

[63] Wright RW, Ricks DA. Trends in international business research: twenty-five years later. J Int Bus Studies 1994; 25: 687-701.

[64] Sinkovics R, Bell J. Current perspectives on international entrepreneurship and the Internet. J Int Entrepreneurship 2005; 3(4): 247-9.

[65] Gabrielsson M, Kirpalani VHM. Born globals: how to reach new business space rapidly. Int Bus Rev 2004; 13(5): 555-71.

[66] Ibeh K, Johnson JE, Dimitratos P, Slow J. Micro multinationals: some preliminary evidence on an emergent 'star' of the international entrepreneurship field. J Int Entrepreneurship 2004; 2(4): 289-303.

[67] Heslop TA. How Strange the Change from Major to Minor: Hierarchies and Medieval Art. In: Dormer P, Ed. The culture of craft Manchester University Press: Manchester 1997.

[68] Welch E. Art and society in Italy 1350-1500. Oxford. Oxford University Press 1997.

[69] Naylor G. The arts and crafts movement. Great Britain. Studio Vista 1971.

[70] Aslin E. The aesthetic movement - prelude to art nouveau. London. Ferndale Editions 1981

[71] Dormer P. The Salon de Refuse? In: Dormer P, Ed. The culture of craft - status and future. Manchester. Manchester University Press 1997.

[72] Danto A. The transfiguration of the commonplace. Cambridge, MA. Harvard University Press 1981. 
[73] Metcalf B, Craft and Art, Culture and Biology. In: Dormer P, Ed. The culture of craft - status and future. Manchester. Manchester University Press 1997.

[74] Myerscough J. The arts and the Northern Ireland economy. Belfast. Northern Ireland Economic Council 1996.

[75] Department for Culture, Media and Sport Creative Industries Mapping Document, update London 2001.

[76] Anderson DR, Sweeney DJ, Williams TA. Statistics for business and economics, $6^{\text {th }}$ ed. USA. West Publishing Company 1996.
Silverman D. Interpreting qualitative data: methods for analysing talk, text and interaction. London. Sage Publications 2001.

Steinmann H, Kumar B, Wasner A. Conceptualising the internationalization process of medium-sized firms. Some preliminary considerations for a research design. Man Int Rev 1980; 20(1): 5066.

Sharma DD, Blomstermo A. The internationalization process of born globals: a network view. Int Bus Rev 2003; 12(6): 739-53.

Received: July 25, 2008

(C) Ian Fillis; Licensee Bentham Open.

This is an open access article licensed under the terms of the Creative Commons Attribution Non-Commercial License (http://creativecommons.org/licenses/by$\mathrm{nc} / 3.0 /$ ) which permits unrestricted, non-commercial use, distribution and reproduction in any medium, provided the work is properly cited. 